\title{
Increasing Productivity of Lentil (Lens culinaris) using Improved Varieties under Alluvial Soil of Uttar Pradesh by Cluster Front Line Demonstrations
}

Omkar Singh ${ }^{1}$, Dharmendra Kumar Singh ${ }^{1}$, Abhishek Singh ${ }^{4}$,

Rajendra Pratap Singh ${ }^{2}$, Sunita Pandey ${ }^{3}$, Ashish Kumar Bajpai ${ }^{1}$

10.18805/LR-4704

\begin{abstract}
Background: Pulses are one of the major crops in India and is better for income generation as well as nutritional security. Pulses are the dry edible seeds of pod plants and are high in protein and fibre and low in fat. Lentils are a pulse crops that is part of legume family. But the productivity of lentil is low in Ghazipur district due to unavailability of quality seed and unawareness of improved crop production technology. It is felt that there is shortage of quality seeds of newer varieties of pulses.

Methods: The present study carried out by Krishi Vigyan Kendra, PG College Ghazipur through cluster front line demonstrations (CFLD) on lentil (Masoor) using improved varieties PL-8 and IPL-316 with seed rate @40 kg/ha. The 135 demonstration were conducted during Rabi season of the year 2017-18, 2018-19 and 2020-21 in three clusters of Devkali block of district Ghazipur. The soils condition was sandy loam in texture having low in $\mathrm{pH}$ with 6.2- 6.9, Organic carbon $(0.39-0.4 .3 \%)$ and available $\mathrm{P}_{2} \mathrm{O}_{5}(18-21 \mathrm{~kg} / \mathrm{ha})$ and medium in $\mathrm{N}$ and $\mathrm{K}$ content.

Result: The technology of improved variety viz. PL-8 and IPL-316 increased the average productivity by $32.53 \%, 59.69 \%$ and $44.85 \%$ and increased the net return by Rs. $15,431.00$, with an improved B:C ratio of 3.34 instead of 2.54, Rs. $24,572.00$ with an improved B:C ratio of 3.58 instead of 2.42 and Rs. 20,585.00 with an improved B:C ratio of 3.93 instead of 2.97 than those of local check variety choti masoor during the three consecutive years respectively. Soil health and soil nitrogen was also improved along with better nodulation in the demonstration plots.
\end{abstract}

Key words: B:C ratio, Cluster front line demonstration (CFLD), Lentil, Net return, Soil health, Yield.

\section{INTRODUCTION}

Pulses are the second most important group of crop after cereals. Globally more than two dozen pulse crops are grown. India is one of the major pulse producing countries contributing about 33 per cent of world area and 25 per cent of world production of pulses. Pulses are also an important component of Indian agricultural economy next to food grains and oilseeds in terms of acreage, production and economic value (Choudhary, 2009). The important pulse crops in India are chick pea, pigeon pea, mung bean, urd bean, lentil and field pea (Ali and Gupta 2012). However India's rank in productivity is low, $24^{\text {th }}$ in chickpea, $9^{\text {th }}$ in pigeon pea, $23^{\text {rd }}$ in lentil and $98^{\text {th }}$ in total pulses (Reddy, 2004). In India, production of pulses is around 19.3 million tonnes (ESI, 2015) with a very low average productivity of $764 \mathrm{~kg} / \mathrm{ha}$. Currently, total area under pulses is 26.3 million ha (Choudhary and Suri, 2014). However, in the case of Lentil, the average yield in India $(629 \mathrm{~kg} / \mathrm{ha})$ is 25 per cent lower than the world average (1053 kg/ha) (FAO, 2007). There is a stark decline in the availability of pulses in the country from $69 \mathrm{~g} /$ capita/day in 1961 to $33 \mathrm{~g} / \mathrm{capita} /$ day in 2009-10 (ICMR recommends $65 \mathrm{~g} /$ day/capita) (Ali and Gupta 2012). To overcome the problem of protein energy malnutrition, a minimum of $50 \mathrm{~g}$ pulses/capita/day should be available in addition to other sources of protein. Thus, to make the nation pulse sufficient, average yield level has to increase substantially up to $1200 \mathrm{~kg} / \mathrm{ha}$ by 2020 (The Hindu 2005).
${ }^{1}$ Krishi Vigyan Kendra, P.G College, Ghazipur-233 001, Uttar Pradesh, India.

${ }^{2}$ Krishi Vigyan Kendra, West Chamapran, Narkatiyaganj-845 455 , Bihar, India.

${ }^{3}$ Mahatma Gandhi Kashi Vidyapeeth, Varanasi-221 002, Uttar Pradesh, India.

${ }^{4}$ Sardar Vallabhbhai Patel University of Agriculture and Technology, Modipuram, Meerut-250 110, Uttar Pradesh, India.

Corresponding Author: Omkar Singh, Krishi Vigyan Kendra, P.G College, Ghazipur-233 001, Uttar Pradesh, India.

Email: omkar.singh39734@gmail.com

How to cite this article: Singh, O., Singh, D.K., Singh, A., Singh, R.P., Pandey, S. and Bajpai, A.K. (2022). Increasing Productivity of Lentil (Lens culinaris) Using Improved Varieties under Alluvial Soil of Uttar Pradesh by Cluster Front Line Demonstrations. Legume Research. DOI: 10.18805/LR-4704

Submitted: 22-06-2021 Accepted: 17-12-2021 Online: 21-02-2022

Due to the mismatch between supply and demand of pulses, prices of pulse crops have increased exorbitantly. Even though pulses are very important for India in terms of share of production and consumption, in term of importance, both farmers and government have ignored them. In India, the irrigated area under pulses was only 12 per cent, while under wheat and paddy, it was more than 60 per cent of the total area. (Materne and Reddy, 2007; Reddy, 2009). Out of 14 
Mt of pulses production, lentil contributes about $1.0 \mathrm{mt}$. Lentil is an important rabi pulse crop next to gram. It's share in the acreage and production of total rabi pulses is about 12 per cent, whereas in the overall pulses production. It's share is about 6 per cent. Lentil has shown a positive growth rate during both the periods (6.67 per cent per annum during 1982-1993 and 1.45 per cent per annum during 1994-2009). In the global context, India is the largest producer of lentil. During the post-WTO regime, the export potential lentil has increased since India is the largest producer of pulses in the world. It indicates the need for wider adoption of lowcost technology among all pulse crops so as to meet the growing domestic as well as global demand. Among all pulses, lentil is the most actively traded pulse crop (about 25 per cent of world production is internationally traded). Uttar Pradesh accounts $40 \%$ of area and $45 \%$ of the total lentil production. Therefore, raising productivity may be the important option to deal with it Kokate et. al. (2013). Uttar Pradesh, which is the second largest producer of lentil, registered a marginal improvement in productivity from 8 qt//ha in 2009-2013 to 8.3 qt//ha in 2014-2018. Uttar Pradesh still remains at the bottom among major lentil producing States, so there is a need to further improve lentil productivity in the State (DES, MoA and FW 2019).

Pulse productivity in India is much lower than other pulse producing countries. This is mainly because of unavailability of quality seed at desired time, cultivation on marginal and sub-marginal lands, injudicious use of fertilizers and non-adoption of crop management practices

Table 1: Nutritional level of lentil.

\begin{tabular}{lc}
\hline Name of foodstuff & Nutitional value $(\mathrm{mg} / 100 \mathrm{~g})$ \\
\hline Protein (\%) & 25 \\
Vit. A (I.U.) & 450 \\
Vit. C & - \\
Vit. K & 0.25 \\
Thiamine & 0.45 \\
Ribo-flavin & 0.49 \\
Nicotinic-acid & 1.5 \\
Biotin $(\mathrm{g} / 100 \mathrm{~g})$ & 13.2 \\
Choline & 299 \\
Folic-acid $(\mathrm{g} / 100 \mathrm{~g})$ & 107 \\
Inositol & 130 \\
Pantothenic-acid & 1.6 \\
Total no. of vitamins/minerals & 11 \\
\hline
\end{tabular}

and poor marketing infrastructure (Chandra, 1994; Choudhary, 2013). So, the National Agricultural Research System including ICAR Institutes, Agricultural Universities, All India Coordinated Research Projects and Krishi Vigyan Kendras to develop and demonstrate new technologies of various pulse crops. A large number of region-specific and widely adapted high yielding short duration varieties of pulses with tolerance to biotic and abiotic stresses have been developed. Kumar and Srivatava (2015) established the impact of reproductive duration on yield in lentil. ICAR has also made sincere efforts in producing required quantity of breeder seeds of major pulse crops. Since 2010-11 ICAR had envisioned to undertake well designed programme of Technology Demonstration for Harnessing Pulses Productivity through KVKs in 137 districts of 11 States by conducting front line demonstrations every year. The results of these CFLD's are very encouraging in showing production potential of various technologies in varying field conditions across the country. These efforts for harnessing pulse production need to be scale up throughout the country in more number of districts identified by the Government under NFSM-Pulses scheme with the financial support from Ministry of Agriculture and Farmer's Welfare, Govt. of India. It is felt that there is shortage of quality seeds of newer varieties of pulses. So, Krishi Vigyan Kendra (KVKs), a vast network of ICAR in the country, can play an important role in demonstrating the improved crop production technologies in farmer's fields and multiplication of seeds. Under the scenario, the programme was undertaken with the following objectives:

- To minimize the problem of low yield of lentil.

- To increase the area, production and productivity of lentil in the district

- To spread the technology of new improved variety throughout the district instead of local variety.

- To increase the benefits of the farmers in the same time and same unit of land.

\section{MATERIALS AND METHODS}

As per the need of protein energy requirement Lentil is good sources of protein and vitamins (Table 1). Lentil production in India is not encouraging and faced up and downs since last few years (Table 2). Uttar Pradesh plays vital role in lentil production in view of area, production and productivity (Table 3). Thus, to make the nation pulse sufficient, average yield level has to increase substantially up to $1200 \mathrm{~kg} / \mathrm{ha}$ by

Table 2: Production of lentil in India.

Unit: Million metric tonnes

\begin{tabular}{lcccccc}
\hline Year & $2013-14$ & $2014-15$ & $2015-16$ & $2016-17$ & $2017-18$ & $2018-19$ \\
\hline Production & 1.02 & 1.04 & 0.98 & 1.22 & 1.61 & 1.23 \\
\hline
\end{tabular}

Source: Directorate of Economics and Statistics (DES), 2019.

Table 3: Area, production and productivity of lentil in Uttar Pradesh.

\begin{tabular}{lccc}
\hline Area (lakh ha) & Per cent share & Production (lakh $\mathrm{t})$ & Per cent share \\
\hline 6.08 & 40.53 & 4.35 & 45.79 \\
\hline
\end{tabular}

Source: Directorate of Economics and Statistics (DES), 2020. 
Increasing Productivity of Lentil (Lens culinaris) Using Improved Varieties under Alluvial Soil of Uttar Pradesh by Cluster Front...

2020 (The Hindu 2005). Due to the mismatch between supply and demand of pulses, prices of pulse crops have increased exorbitantly. Cluster front line demonstrations (CFLD) on lentil (Masoor) using improved varieties PL-8 and IPL-316 were conducted during rabi seasons of the year 2018-19, 2019-20 and 2020-21 respectively in the KVK, P.G. College, Ghazipur, Uttar Pradesh jurisdiction villages to show the higher production potentiality than local check variety. The demonstrations were carried out in 50 farmers' fields of 20 ha. area at village Rampur Manjha, 50 farmers's field in 20 ha. area at village Chadipur and 35 farmer's fields of 10 ha. area at village Naripachdevra of Devkali block in Ghazipur district of Uttar Pradesh during the year 2017-18, 2018-19 and 2020-21 respectively in irrigated medium land and sandy loam soil situation, in different villages of Ghazipur district. The soils were sandy loam in texture having low in $\mathrm{pH}$ with 6.2- 6.9, Organic carbon (0.39-0.4.3\%) and available $\mathrm{P}_{2} \mathrm{O}_{5}(18-21 \mathrm{~kg} / \mathrm{ha})$ and medium in $\mathrm{N}$ and $\mathrm{K}$ content. The problem of low productivity of lentil was analyzed through using participatory rural appraisal (PRA) techniques like focus group discussion and group discussion. From these analyses, it was found out that among the bio-physical constraints, the lack of good quality seed of new improved varieties were ranked first. In this context, the new improved varieties viz. PL-8 and IPL-316 were selected for CFLD to minimize the problem of low yield of lentil. On Campus farmers' training were conducted to aware and impart knowledge about the new improved variety selected for

Table 4: Area, production and productivity of lentil in Ghazipur.

\begin{tabular}{lccc}
\hline Year & Area (ha.) & Production (tonnes) & Yield (t/ha) \\
\hline $2015-16$ & 4761 & 5213 & 1.09 \\
$2016-17$ & 10521 & 11584 & 1.10 \\
$2017-18$ & 11336 & 12311 & 1.09 \\
$2018-19$ & 10376 & 12067 & 1.16 \\
\hline
\end{tabular}

Source: Directorate of Economics and Statistics (DES), 2020. demonstration in the partner farmers' plots. The different features and potentiality of the demonstrated varieties were discussed comparing it to the Local Check Variety i.e. Choti masoor. All the agronomic practices like seed rate, sowing method, Rhizobium inoculation, Phosphate management, weed management, micro-nutrient spraying etc. were discussed thoroughly to get the maximum benefit. The seed of the improved varieties were distributed @ $40 \mathrm{~kg} / \mathrm{ha}$. The sowing in all demonstration plots was completed by $15^{\text {th }}$ November in all three reported years. All other agronomic practices were same as it was practiced in the Local Check plots. The crops were totally managed by farmers. They shared all the inputs except the only critical inputs i.e., seeds of the improved variety which was shared by KVK. At the time of maturity, field visit programmes were conducted in the demonstration plots in the every village. After harvesting and threshing, the yield data were obtained from individual partner farmers plots. For analysis and interpretation, weighted mean of the yield was calculated to obtain the average yield. The reafter total cost of cultivation was calculated on the basis of discussion with farmers. The price of the crop in the local market was taken into consideration for calculation of gross return.

The area, production and producitvity of lentil crop in the Ghazipur district of Uttar Pradesh has been increased from 2015-16 to 2019-20 which is given in the Table 4 .

\section{RESULTS AND DISCUSSION}

The cost of cultivation was higher in Lentil but due to higher price of Lentil in the market as well as MSP (Minimum Support Price) played a great role in such positive economics (Fig 1) of the crop (Table 5). From the (Table 6) it was noted that 50 numbers of cluster front line demonstrations (CFLDs) on improved lentil variety i.e., PL-8 was implemented in 20 ha area during the year 2018-19 and the same number in the year 2019-20 with IPL-316 whereas, numbers of

Table 5: Minimum support price (MSP) of lentil.

(Unit: Rs/Quintal)

\begin{tabular}{lccccccc}
\hline Year & $2014-15$ & $2015-16$ & $2016-17$ & $2017-18$ & $2018-19$ & $2019-20$ & $2020-21$ \\
\hline Price (Rs.) & 3075 & 3400 & 3950 & 4250 & 4475 & 4800 & 5100 \\
\hline
\end{tabular}

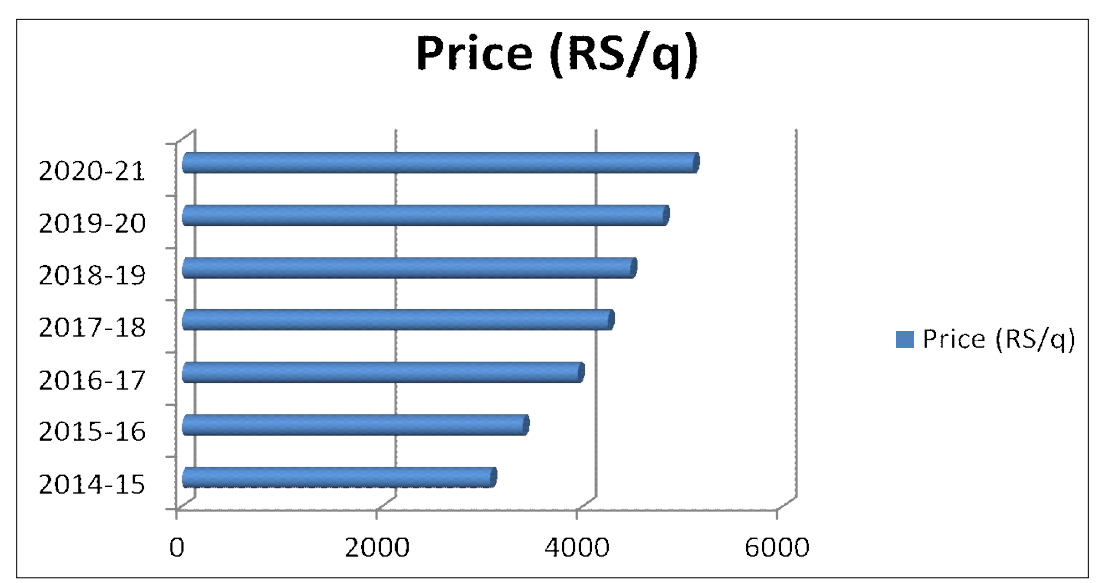

Fig 1: Minimum support price (MSP) of lentil. 
Increasing Productivity of Lentil (Lens culinaris) Using Improved Varieties under Alluvial Soil of Uttar Pradesh by Cluster Front...

Table 6: Implementation of CFLD Programmes on Ientil.

\begin{tabular}{lclcrc}
\hline Year & $\begin{array}{c}\text { Improved } \\
\text { variety }\end{array}$ & Thematic area & $\begin{array}{c}\text { Technology } \\
\text { demonstrated }\end{array}$ & Area (ha.) & $\begin{array}{r}\text { No. of farmers } \\
\text { /Demostration }\end{array}$ \\
\hline $2018-19$ & PL-8 & Varietal replacement & Improved Variety & 20 & 50 \\
$2019-20$ & IPL-316 & Varietal replacement & Improved Variety & 20 & 50 \\
$2020-21$ & IPL-316 & Varietal replacement & Improved Variety & 10 & 35 \\
\hline
\end{tabular}

Table 7: Performance of the front line demonstrations on lentil.

\begin{tabular}{lcccccc}
\hline Year & $\begin{array}{c}\text { Improved } \\
\text { variety }\end{array}$ & Local check & $\begin{array}{c}\text { Average } \\
\text { demonstration } \\
\text { yield }(\mathrm{q} / \mathrm{ha} \text {.) }\end{array}$ & $\begin{array}{c}\text { Local } \\
\text { check yield } \\
(\mathrm{q} / \mathrm{ha})\end{array}$ & $\begin{array}{r}\text { Increase } \\
\text { in yield } \\
(\%)\end{array}$ & $\begin{array}{r}\text { Potential yield } \\
\text { of improved } \\
\text { variety (q/ha.) }\end{array}$ \\
\hline $2018-19$ & $\mathrm{PL}-8$ & Chotimasoor & 13.28 & 10.02 & 32.53 & 18 \\
$2019-20$ & $\mathrm{IPL}-316$ & Chotimasoor & 14.55 & 9.10 & 59.89 & 18 \\
$2020-21$ & $\mathrm{IPL}-316$ & Chotimasoor & 14.92 & 10.30 & 44.85 & 18 \\
\hline
\end{tabular}

Table 8: Economics of the front line demonstrations on lentil.

\begin{tabular}{|c|c|c|c|c|c|c|c|c|c|c|}
\hline \multirow[b]{2}{*}{ Year } & \multirow[b]{2}{*}{ Variety } & \multirow[b]{2}{*}{ Local check } & \multicolumn{4}{|c|}{ Farmers' existing plots (local check) } & \multicolumn{4}{|c|}{ Demonstration plots (improved variety) } \\
\hline & & & $\begin{array}{c}\text { Gross } \\
\text { cost } \\
\text { (Rs./ha.) }\end{array}$ & $\begin{array}{c}\text { Gross } \\
\text { return } \\
\text { (Rs./ha.) }\end{array}$ & $\begin{array}{c}\text { Net } \\
\text { return } \\
\text { (Rs./ha.) }\end{array}$ & $\mathrm{B}: \mathrm{C}$ & $\begin{array}{c}\text { Gross } \\
\text { cost } \\
\text { (Rs./ha.) }\end{array}$ & $\begin{array}{c}\text { Gross } \\
\text { return } \\
\text { (Rs./ha.) }\end{array}$ & $\begin{array}{c}\text { Net } \\
\text { return } \\
\text { (Rs./ha.) }\end{array}$ & $B: C$ \\
\hline 2018-19 & PL-8 & Chotimasoor & 16290 & 41539 & 25249 & 2.54 & 17350 & 58030 & 40680 & 3.34 \\
\hline 2019-20 & IPL-316 & Chotimasoor & 17610 & 42539 & 25070 & 2.42 & 19198 & 68840 & 49642 & 3.58 \\
\hline 2020-21 & IPL-316 & Chotimasoor & 16950 & 50350 & 33400 & 2.97 & 18415 & 72400 & 53985 & 3.93 \\
\hline
\end{tabular}

CFLDs on improved variety i.e., IPL-316 was conducted in 10 ha area during the year 2020-21 considering the thematic area of varietal replacement. The local check old variety i.e., Choti masoor was replaced with the mentioned two improved varieties. In the year 2018-19, the seeds of improved variety PL-8 were available for demonstration. Seeing the success of the programme, the area of the CFLD was repeated in the year 2019-20 and 2020-21 with newer improved variety IPL-316. The perusal of the data (Table 7) on the performance of the CFLDs clearly indicated that average yield of the crop lentil was increased by $32.53 \%$, $59.89 \%$ and $44.85 \%$ in three consecutive years respectively. In the year 2018-19, the average yield of the demonstration of the variety PL- 8 was found $13.28 \mathrm{q} /$ ha which was satisfactorily higher than those of the local check plots having the variety chotimasoor $(10.02 \mathrm{q} / \mathrm{ha})$. Thus it minimized the yield gap by 40.72 per cent with reference to the potential yield of the improved variety i.e., $18 \mathrm{q} / \mathrm{ha}$. Similarly, in the year 2019-20, the average demonstration yield of the variety IPL-316 was found 14.55 q/ha which was remarkably higher than those of the local check yield of the variety Choti masoor i.e., $9.10 \mathrm{q} / \mathrm{ha}$. The yield gap with reference to potential yield of the variety IPL-316 (18 q/ha) was reduced by 61.23 per cent and in the year 2020-21 the average demonstration yield of the variety IPL-316 was found 14.92 q/ha which was remarkably higher than those of the local check variety yield i.e., $10.30 \mathrm{q} / \mathrm{ha}$. The yield gap with reference to potential yield of the variety IPL-316 was reduced by 60.0 per cent using the technology of improved variety. In Raisen, Madhya Pradesh Dubey et al.,(2017) observed similar result in FLD on chickpea. Considering the economics of the programme
(Table 8), it might be depicted that demonstration of improved variety fetched higher $\mathrm{B}: \mathrm{C}$ ratio of $3.34,3.58$ and 3.93 in comparison to $2.54,2.42$ and 2.97 as reported in the local check during 2018-19, 2019-20 and 2020-21 respectively. It implied that CFLD on improved variety of lentil not only increased the yield but also fetched higher benefit cost ratio to tune of 31.50 per cent, 47.93 per cent and 32.32 per cent during all three consecutive years respectively. Extra net returns of Rs. 15,431.00/ha, 24572.00/ha. and Rs. 20,585.00/ha during the year 2018$19,2019-20$ and 2020-21 were obtained due to higher yield potential of the improved variety. This might be due to suitability of those varieties to the micro-climatic situation and soil condition of Ghazipur district. Similar type of results were obtained by Shah et al. (2020) and Yadav et al. (2015), where improved varieties IPL-316 and PL-8 performs highest yields at North east agro ecological areas of India and Mandal et al. (2019) also stated that improved variety of Lentil can be used to minimize the yield gap and increase the area for pulse production. Higher yields of the improved varieties (IPL-316 and PL-8) were obviously due to their genital character and of more root ramification and better nodulation of the crop. Thus decaying of large number of roots and nodules improved the soil organic carbon and available nitrogen content after the harvest of the crop and thus maintained the soil health and sustainability. Singh et al. 2020 also found the significant increase in yield attributes of lentil variety PL-8 due to introduction of new varieties when introduced to Maharajganj district of Uttar Pradesh. 
Increasing Productivity of Lentil (Lens culinaris) Using Improved Varieties under Alluvial Soil of Uttar Pradesh by Cluster Front...

\section{CONCLUSION}

After completion of the CFLD programmes, it might safely be stated that improved variety of lentil were found successful to minimize the yield gap and to increase the area, production and productivity of lentil in the Ghazipur district of Uttar Pradesh. Further it may also be noted that replacement of old local variety of lentil may successfully be adopted by using the improved varieties of PL-8 or IPL316. Beside the vertical improvement of the productivity of lentil, horizontal spread of the technology is also ensured due to improvement of economics of production of Lentil in specific and pulse in broad sense. Therefore, farmers will be definitely benefited by cultivation of Lentil using the improved varieties PL-8 and IPL-316 after kharif Paddy in lateritic, sandy loam soil of Ghazipur District of UttarPradesh in a sustainable manner.

Conflict of interest: None.

\section{REFERENCES}

Ali, M. and Gupta, S. (2012). Carrying capacity of Indian agriculture: Pulse crops. Current Science. 102 (6): 874-881.

Chandra, S. (1994). Increasing pulse production in India, Proceedingsof Symposium on Increasing Pulse Production in India-Constraints and opportunities, October 1994, New Delhi. pp. 23-39.

Choudhary, A.K. (2009). Role of phosphorus in pulses and its management. Indian Farmers' Digest. 42 (9): 32-34.

Choudhary, A.K. (2013). Technological and extension yield gaps in pulses in Mandi district of Himachal Prades. Indian Journal of Soil Conservation. 41(1): 88-97.

Choudhary, A.K. and Suri, V.K. (2014). Scaling up of pulses production under frontline demonstrations technology programme in Himachal Himalayas, India. Communication in Soil Science and Plant Analysis. 45: 1934-1948.

Dubey, S., Raghav, R.S. and Singh, P. (2017). Enhancement of Productivity for chickpea (Cicer arietinum L.) through front line demonstration in Farmers' Fields. Legume Research. 40: $335-337$
ESI. (2015). The Economic Survey 2014-15. The Economic Survey of India, New Delhi. FAO. (2007).

FAOSTAT. http://faostat.fao.org/site/526/default/aspx. Food and Agriculture Organization of the United Nations, Rome, Italy.

Kokate, K.D., Singh A.K. and Singh Lakhan (2013). Harnessing Pulses Productivity. Published by Division of Agricultural Extension, ICAR, New Delhi.

Kumar, J. and Srivatava, E. (2015). Impact of reproductive duration on yield and its component traits in lentil. Legume Research. 38(2): 139-148.

Mandal, S., Ray, P., Mondal, S. and Ankure, P. (2019). Front line demonstration on lentil using improved varieties for increasing productivity under lateritic soil of West Bengal. Legume Research. 42(3): 426-429.

Materne and Reddy, A.A. (2007).Commercial Cultivation and Profitability, In: The Lentil-An Ancient Crop for Modern Times. [S.S. Yadav, David Mc Neil, Philip, C. Stevenson, Springer (Eds.)] Rotterdam, The Netherlands. pp. 173186.

Reddy, A.A. (2004). Consumption pattern, trade and production potential of pulses. Economic and Political Weekly. 39(44): 4854-4860.

Reddy, A.A. (2009). Pulses production technology: Status and way forward. Economic and Political Weekly. 44(52): 73-82.

Sah, D., Kumar, M. and Singh, S. (2020). Evaluation of lentil varieties under foot hill of north east agro-ecological region of India. Journal of Pharmacognosy and Phyto chemistry. 9(5): 1084-1087.

Singh, D.P., Chandra, V. and Tiwari, T. (2020). Increase Intil (Lens culinaris) production through cluster frontline demonstrations of Maharajganj, Eastern U.P., India. International Journal of Current Microbiology and Applied Sciences. 10: 314-322.

The Hindu. ( 2005). The Hindu Survey of Indian Agriculture.

Yadav, G.S., Datta, M., Saha, P., Debbarma, C. (2015). Evaluation of lentil varieties/lines for utilization of rice fallow in Tripura. Indian Journal of Hill Farming. 28(2): 90-95. 